\title{
Język $i$ styl twórcy w kręgu badań współczesnej humanistyki. Studia o języku i stylu artystycznym, t. V. Red. Krzysztof Maćkowiak, Cezary Piątkowski
}

Zielona Góra 2009, ss. 332

Prezentowany tom - składający się z 30 odrębnych tekstów - jest kolejną już publikacją z serii Studiów o języku i stylu artystycznym, przygotowaną przez zespół językoznawców Uniwersytetu Zielonogórskiego. Niewątpliwą zaletą poznawczą tomu - co należy już na wstępie podkreślić - jest jego interdyscyplinarność, pozwalająca spojrzeć na procesy tekstotwórcze z perspektywy różnorodnych dziedzin badawczych, np. antropologii, estetyki, filozofii, literaturoznawstwa czy językoznawstwa i to zarówno diachronicznego, jak i współczesnego.

Książkę otwiera artykuł Marii Bielawki pt. Metafizyczność twórcy: poezja Zbigniewa Herberta (s. 7-22). Autorka podejmuje próbę - zgodnie $\mathrm{z}$ egocentrycznym nastawieniem badawczym - doprecyzowania metafizyczności twórcy, „którego można odczytać czy też wyinterpretować wprost z dzieła" (s. 8). Przeprowadzana analiza - utworów różnych pod względem formalnym, objętościowym i tematycznym - dowodzi, że w twórczości poety zarówno ukryty (jak też wskazywany bezpośrednio podmiot liryczny) prezentuje postawę oraz cechy osobowości, jeśli nie tożsame, to przynajmniej bliskie autorowi. Efektem osadzenia Herbertowskiej twórczości w szerokim kontekście filozoficzno-estetyczno-etycznym staje się merytorycznie uzasadniony wniosek, że badana poezja jest "wehikułem pasji i cnoty", że zawiera "nie tyle samo piękno, ile piękno, które ocala".

Jerzy Biniewicz $\mathrm{w}$ artykule Styl wystapień politycznych $w$ mediach (s. 23-32), wychodząc od osadzenia pojęcia stylu w badaniach poświęconych dyskursowi, wyznacza parametry zewnętrznojęzykowe określające 
przyczynę zachowań językowych oraz ustala czynniki budujące tzw. ramę pragmatyczną. Stara się też zlokalizować źródło środków językowych, ustalić ich charakterystyczny dla określonych form kontaktu układ oraz zasygnalizować nośność funkcjonalną poszczególnych elementów stylotwórczych. W wyniku przeprowadzonej analizy badacz zauważa, że język politycznego dyskursu jest użytecznym narzędziem w konstruowaniu określonego, ściśle wystylizowanego i zsubiektywizowanego obrazu rzeczywistości. Co więcej, im komunikat jest bardziej demagogiczny, insynuacyjny, ostrzejszy w tonie, tym staje się bardziej przydatny $\mathrm{w}$ budowaniu politycznego, skonfliktowanego świata.

Barbara Bogołębska analizuje Style Ryszarda Kapuścińskiego (s. 33-40) z punktu widzenia literaturoznawcy. Autorka wyznacza nadrzędną tezę o nierozerwalności perspektywy stylistycznej i gatunkowej, zwraca uwagę na „pisanie niefikcyjne” Kapuścińskiego, jego własne, odrębne style, warsztatową perfekcję czy chociażby niepowtarzalną odmianę reportażu, określaną niekiedy magiczną.

Interesujące rozstrzygnięcia przynosi artykuł Jerzego Brzezińskiego O niektórych środkach ekspresji językowej w prozie Stefana Żeromskiego (s. 41-54). Jest to kolejny już tekst, w którym badacz przedstawia walory językowego mistrzostwa pisarza. Tym razem rozpatruje zróżnicowanie leksykalne i stylistyczne epitetów w Popiołach oraz szeregów słownych w Przedwiośniu i wprowadzając je w kontekst szeroko pojętej stylistyki, wyznacza liczne określenia epitetowe kolorystyczne bądź ekspresywne, odnoszące się do przyrody i postaci. Opisuje również ekspresywną funkcję stylistyczną szeregów, wpływających na plastykę obrazowania artystycznego oraz uwydatnienie ambiwalencji w opisie bohaterów i otaczającego ich świata.

Artykuł Z zagadnień stylu powieści Teodora T. Jeża Beaty Cisowskiej (s. 55-63) stanowi swoistą rejestrację słownictwa obcego (np. rusycyzmów, ukrainizmów, zapożyczeń francuskich, zapożyczeń tureckich), archaizmów oraz porównań, hiperboli i sentencji wyekscerpowanych z powieści pisarza - Wasyl Hotub.

Kolejny tekst Talent oratorski króla Stanisława Augusta Poniatowskiego Małgorzaty Dawidziak-Kładocznej w zwięzły sposób przedstawia walory perswazyjne mów sejmowych ostatniego monarchy Polski. Przedmiotem opisu stają się chwyty i strategie ukierunkowane na pozyskanie odbiorcy (pochlebstwa, etykietalne akty mowy, dyrektywy) oraz akty mowy skierowane na nadawcę (chwalenie się, neutralizacja chwalenia się, inne eks- 
presywne akty mowy). I chociaż - jak twierdzi badaczka - „analiza merytorycznej zawartości mów Stanisława Augusta pokazuje jego monarsze słabości, to forma wystąpień, której wybór był wynikiem sytuacji politycznej i ustrojowej w Polsce, może budzić podziw dla elokucji władcy i podziw dla niego".

Dużym stopniem szczegółowości opisu odznacza się tekst Andrzeja S. Dyszaka Orzeczenie analityczne w nowelach $i$ opowiadaniach pisarzy polskich jako przedmiot opisu stylu (s. 75-85). Przedmiotem rozważań badacz uczynił „pewne składniowe cechy stylu wybranych pisarzy polskich (...), reprezentujących dwa pokrewne kierunki, jakimi są nowela i opowiadanie" okresu pozytywizmu. Wyekscerpowany $z$ analizowanych źródeł materiał omówił na tle różnych - w zakresie składni stylistycznej - metod badawczych i na tej podstawie podjął godną uwagi próbę opisu orzeczenia analitycznego, które w tekstach artystycznych może być wykorzystywane jako jeden $\mathrm{z}$ wariantów synonimicznych $\mathrm{i}$ w ten sposób może stanowić interesujący przedmiot opisu stylistyki, nie tylko gramatyki.

Joanna Frejman $\mathrm{w}$ artykule Leksyka somatyczna w utworach poetyckich Brunona Jasieńskiego (s. 87-92) skupia się na analizie połączeń wyrazowych zawierających nazwy części ciała. Dostrzega walor oceniająco-wartościujący somatyzmów, eksponuje ich depoetyzacyjną funkcję i wiążące się $\mathrm{z}$ nimi negatywne konotacje, a przede wszystkim sugeruje, że omawiana kategoria leksykalna wydaje się cennym wyróżnikiem idiolektu poety.

Kolejny tekst jest pokłosiem lektury pism uczonego-dominikanina, filozofa, etyka, pedagoga żyjącego na przełomie XIX i XX wieku. Anetta Gajda omawia Popularno(naukowy) styl o. Jacka Woronieckiego (s. 93-104), zwracając uwagę na stosowane przez uczonego zabiegi popularyzatorskie oraz umiejętność łączenia pierwiastków naukowo-teoretycznych z pierwiastkami społeczno-edukacyjnymi.

Celem Joanny Gorzelany w artykule Styl poezji Jana Pawła Woronicza (na przykładzie utworu "Na pokoje nowe w Zamku Królewskim...") (s. 105-117) jest przedstawienie wykładników o określonej wartości stylistycznej, kształtujących uwarunkowaną gatunkowo podniosłość panegiryku. W jasno skonstruowanym wywodzie badaczka udowadnia, że w utworze Woronicza funkcję stylotwórczą pełnią różne elementy. W obrębie systemu gramatycznego są to złożenia, w płaszczyźnie pragmatycznej - poetyzmy, w zakresie kręgu kulturowego - biblizmy, mitologizmy i nazwy własne w funkcji historyzmów. 
Kapłaństwo jako determinanta idiostylu wypowiedzi poetyckiej Karola Wojtyły (na wybranych przykładach) (s. 119-129) to tytuł artykułu Barbary Greszczuk o języku młodzieńczej poezji przyszłego papieża. Autorka w przekonujący sposób eksponuje wielotorowość i synkretyzm kapłańskiego, poetyckiego obrazowania oraz tkwiących w stylizacji biblijnej nawiązaniach do stylu psałterzowo-biblijnego. Omawia stylotwórczą funkcję zasad metrum poezji hebrajskiej, biblijnych archetypów, retorycznych rejestrów oraz leksyki i frazeologii o proweniencji biblijnej.

Artykuł Magdaleny Hawrysz Determinanty stylotwórcze "Rozmów chrystyjańskich" Marcina Czechowica (s. 131-140) dotyczy tekstu szesnastowiecznego aktywnego polemisty, przywódcy najradykalniejszego odłamu arian. Autorka w swoim szkicu wskazuje cechy stylowe dzieła: ponadindywidualne lub inaczej obiektywne (uwarunkowane tradycją gatunku, czasem, historią) oraz zindywidualizowane (wynikające ze sposobu obrazowania i realizacji językowych strategii).

Leksykalne właściwości języka pism naukowych Joachima Lelewela stały się przedmiotem badań Violetty Jaros (s. 141-150). Autorka ustala osobnicze zachowania językowe najwybitniejszego dziewiętnastowiecznego badacza dziejów Polski, często znacznie wykraczające poza pewne kanony stylu naukowego. Wśród wyznaczników Lelewelowskiej prozy wymienia: celność i precyzję, celność i perswazyjność argumentów, a także obiektywizm przejawiający się $\mathrm{w}$ naukowej kategoryzacji rzeczywistości obok emocjonalności, również obecność elementów leksykalnych o wyrazistym i często sprzecznym nacechowaniu stylowym (np. archaizmy i słownictwo przestarzałe skontrastowane $\mathrm{z}$ neologizmami, albo $\mathrm{z}$ kolei słownictwo terminologiczne obok potocyzmów itp.).

Jan Kida w artykule Funkcje semantyczne i stylistyczne słownictwa obcego w powieści historycznej "Na polu chwały” Henryka Sienkiewicz (s. 153-167) dokonuje rzeczowej, bardzo przy tym interesującej i - mimo szczupłych ram tekstu - wieloaspektowej interpretacji wyekscerpowanego materiału. Charakteryzuje kategorie części mowy, wyrazy zapożyczone, kategorie semantyczne słownictwa obcego, cytaty obcojęzyczne i ich semantykę oraz funkcję stylistyczną obcego słownictwa w charakterystyce postaci literackich, środowisk społecznych oraz innych zjawisk. Tekst kończy się zwartym podsumowaniem przedstawiającym nie tylko wyniki przeprowadzonej analizy, ale też wskazującym te aspekty badawcze, które powinny stać się przedmiotem odrębnych badań lingwistycznych. 
"Mowa duchowna przy szlubie" Piotra Mohyly. Prawostawna realizacja stylu religijno-kościelnego (s. 169-176) - artykuł Jolanty Klimek - jest próbą poszukiwania $\mathrm{w}$ barokowym kazaniu ślubnym, wygłoszonym przez prawosławnego hierarchę wyodrębnionych przez A. Wilkonia dziewięciu cech stylu religijno-kościelnego. Przeprowadzona przez lubelską badaczkę analiza prowadzi do wniosków, że w tekście Mohyły uwidaczniają się wpływy dwóch typów czynników stylotwórczych (teologiczno-wyznaniowych i poetycko-barokowych), zaskakuje wyraźna dominacja retoryczności nad panegiryzmem, pojawiają się elementy polemiki, a na plan pierwszy zdecydowanie wysuwają się ideologiczność i stereotypowość.

Celem artykułu Piotra Kładocznego Świat dźwięków w twórczości Manueli Gretkowskiej (s. 177-191) jest przedstawienie i analiza leksyki związanej z percepcją słuchową, a wyekscerpowanej ze wszystkich niemal wydań książkowych pisarki. Słownictwo to podlega wielopłaszczyznowej charakterystyce. Autor zwraca uwagę na uwarunkowania jakościowe i ilościowe leksyki, interpretuje innowacje leksykalne i semantyczne, zajmuje się konceptualizacją dźwięku oraz czynnikami stylistyczno-pragmatycznymi służącymi do kreowania świata przedstawionego.

Artykuł Lingwistyczne metody badania tekstów poetyckich w aspekcie refleksji nad idiostylem - zagadnienie perswazji na przykładzie utworów Jana Twardowskiego (s. 193-205) Jolanty Kowalewskiej-Dąbrowskiej podejmuje jeden $\mathrm{z}$ aspektów związanych $\mathrm{z}$ badaniami nad idiostylem, mianowicie charakteryzuje przejawy funkcji perswazyjnej $w$ utworach poetyckich jednego z najbardziej znanych polskich poetów współczesnych. Rzeczowa, językoznawcza analiza potwierdza niebywałość kunsztu Twardowskiego, który $\mathrm{z}$ lekkością potrafił łączyć funkcję artystyczną z dyskursywnością, perswazją i dydaktyzmem.

Spojrzenie literaturoznawcy na problem stylu odnajdujemy w artykule Anny Krysztofiak Epos podobny $z$ twarzy do innych (o pierwszym rapsodzie „Króla Ducha”) (s. 207-215). Autorka zwraca uwagę na niektóre cechy językowe badanego dzieła (np. zdania wielokrotnie złożone, skłonność do retorycznej składni, wprowadzanie wyrazów potocznych $\mathrm{w}$ niezwykłe otoczenie semantyczne, wprowadzanie kolorytu miejsca za pomocą wyrazów ukraińskich itp.).

Michał Kř́stek z Uniwersytetu w Brnie w swoim tekście Rezultativní teorie stylu a styl Karla Polácka (1892-1945) - nẻkolik možností ke zkoumaní (s. 217-221) przedstawia pojęcie stylu na przykładzie autorskiego stylu Karla Polaczka, jednego ze znaczniejszych przedstawicieli czeskiej 
literatury pierwszej połowy $\mathrm{XX}$ wieku. Artykuł ma budowę trójdzielną: część pierwsza poświęcona jest najważniejszym informacjom dotyczącym pisarza i jego twórczości, część druga - skróconym z konieczności rozważaniom teoretycznym opartym na założeniach szkoły praskiej, część trzecia - zasygnalizowaniu najistotniejszych wyznaczników stylotwórczych pisarza.

Artykuł Słowiańska legenda Stacha z Warty Szukalskiego Iwony Loewe (s. 223-230) poświęcony jest dramatowi Krak syn Ludoli, w szczególności zaś znamiennej dla autora - Stanisława Szukalskiego - predylekcji językowej widocznej zwłaszcza w leksyce. Pisarz urodzony w Warcie koło Sieradza w 1893 roku, rzeźbiarz, dziennikarz, dramaturg, wnikliwy czytelnik pism Rozwadowskiego i Brücknera, nasycił swój utwór neologizmami i neosemantyzmami, ekspresywizmami, elementami gwarowymi, elementami parodystycznymi i wizjonerskimi. $Z$ tego powodu - jak pisze badaczka - w swym wymiarze edytorskim, metatekstowym i stylistycznym utwór zasługuje na uwagę językoznawcy.

Ewa Malinowska w swoim zwięzłym, merytorycznym szkicu Twórca tekstu urzędowego (s. 231-238) skupia się na zagadnieniach: „kim jest twórca nakazów i zakazów, wyznaczający obowiązki powinnego zachowania? Czy bliżej nieokreślonym decydentem, ukrywającym swoją podmiotowość za instytucją, którą reprezentuje, czy indywidualną osobą fizyczną? Jakich kompetencji wymaga się (oczekuje) od twórcy tekstu urzędowego?". Przeprowadzona analiza prowokuje badaczkę do rzeczowo uzasadnionego wniosku, że w komunikacji urzędowej daje się zauważyć asymetrię kompetencji komunikacyjnej jej uczestników, np. stosunkowo wysokiej kompetencji merytorycznej urzędników towarzyszyć może brak dostatecznej kompetencji językowo-stylistycznej, ale z kolei wśród przeciętnych obywateli niezadowalająca jest zarówno znajomość kultury prawnej, jak i elementarnych zasad redagowania i odczytywania tekstu normatywnego.

Tekst Anny Małeckiej Twórca wobec nieistnienia: Rafał Wojaczek (s. 239-246) jest spojrzeniem na dzieło artystyczne z perspektywy filozoficzno-estetycznej. Metaforycznie nicość jest rozpatrywana w kontekście śmierci, w kontekście wątpliwej tożsamości osobowej oraz twórczości poetyckiej.

Metodologiczny artykuł Jolanty Nocoń Autor tekstu i autor w tekście dydaktycznym (s. 247-255) skupia się na - uwarunkowanych różnorodnymi czynnikami - działaniach tekstotwórczych autora. Badaczka zakłada, że 
$\mathrm{w}$ procesie tym istotnymi elementami są indywidualne cechy twórcy tekstu, a więc: jego doświadczenie jako autora, poziom jego kompetencji językowokomunikacyjnej, wiedza merytoryczna, przekonania, idee i wartości. Aspektów osobniczych nie da się jednak oddzielić - jak udowadnia - J. Nocoń od konwencji dyskursywno-gatunkowej, w istotny sposób ograniczającej autora i narzucającej mu określone rozwiązania, choćby wykorzystanie określonego wzorca gatunkowego.

Krzysztof Skibski podejmuje problem kategorii elipsy wersowej ściśle związanej z koncepcją językowego odbioru dzieła literackiego. Jego tekst Morfologiczna elipsa wersowa jako figura idiostylu (s. 257-266) zwraca uwage na stosunkowo rzadką - dookreślającą kategorię idiostylu - cechę: implikację morfologiczną ujawnianą w postaci elipsy sylabicznej oraz morfologiczną elipsę słowotwórczą. Dzięki przeprowadzonej analizie badacz sygnalizuje złożoność problematyki oraz wyznacza niezbędne kierunki interpretacyjne.

Ewa Sławkowa - w refleksji nad językiem osobniczym - definiuje cele badawcze stylistyki, a przede wszystkim sytuuje ją w szerokim kontekście innych dziedzin humanistycznych. Artykuł Jezzyk pisarza jako metodologiczny problem stylistyki (s. 267-278) eksponuje różnicę postaw i odmienność perspektyw badawczych, ,jakie w odniesieniu do badanej problematyki podejmują z jednej strony językoznawcy, a z drugiej historycy i teoretycy literatury". Owo zróżnicowanie metodologiczne zostaje skomentowanie i objaśnione za pomocą skrupulatnych odwołań do bogatej literatury przedmiotu, wykorzystującej różnorodne narzędzia opisu, które - jak wynika z przeprowadzonej analizy językoznawczej - mogą jawić się często jako niejednoznaczne i niekomplementarne. Prowadzić to może do trudności z wyznaczeniem autonomii i tożsamości twórcy, a ma to - zdaniem badaczki - większe znaczenie niż dylematy terminologiczne.

Szczegółowym aspektom języka osobniczego poświęcony jest tekst Magdaleny Smoleń-Wawrzusiszyn Hiperbola $i$ kontrast jako mechanizmy satyry $w$ felietonach Jędrzeja Śniadeckiego (s. 279-288). Autorka - analizując różne teksty publicystyczne uczonego, częściej utożsamianego raczej z naukami biologiczno-chemicznymi oraz filozofią niż czasopiśmiennictwem - zajmuje się środkami stylistycznymi, które realizują konwencję satyry jako sposobu wypowiedzi. Szczegółowy rejestr tych środków stanowi skromną - jak sugeruje badaczka - próbkę parodystycznych umiejętności Śniadeckiego, który kontrast i hiperbolę stosował świadomie w celu uwypuklenia absurdalnego charakteru opisywanej rzeczywistości. 
Z zainteresowań translatoryką wyrasta tekst Doroty Szagun Tłumaczenie jako źródło badań nad językiem i stylem twórcy (Brodziński - Ujejski) (s. 289-297). Za podstawę materiałową przyjęto w artykule dwa tłumaczenia biblijnej Pieśni nad pieśniami, a następnie wskazano „poetyckie preferencje dwóch różnych poetów, o różnym doświadczeniu twórczym, dorobku literackim i upodobaniach stylistycznych, choć jednocześnie włączonych w jedną epoką literacką". Przeprowadzona lingwistyczna analiza porównawcza wykazała, na ile trwałe i uniwersalne są jedne środki stylistyczne, na ile zaś drugie mogą nosić na sobie piętno idiostylu autorskiego.

Tekst instrukcji obsługi za kategorię stylową uznaje Wiesława Troszczyńska-Nakonieczna w swoim artykule Spójność referencjalna w instrukcji obstugi - dominanta stylistyczna? (s. 299-311). Prowokacyjnie wprowadzony $w$ tytule znak zapytanie sugeruje, że mamy do czynienia wyłącznie z przypuszczeniem, choć dalsze rozważania autorki nie pozostawiają wątpliwości. Instrukcja obsługi jest komunikatem szczególnym, w którym równorzędną rolę odgrywają szczegółowo opisane aspekty wizualne i aspekty werbalne, kształtujące dominantę stylistyczną, opartą na konsekwencji, zwięzłości, jasności i schematyczności przekazu.

Stylistyka dyskursu - nowe horyzonty badań nad stylem autora Bożeny Witosz (s. 313-320) wprowadza odbiorcę w problematykę i szerokie spektrum praktyk dyskursywnych, a także prowokuje do wieloaspektowego oglądu mowy jednostkowej. Badaczka - z właściwą sobie erudycją - przywołuje koncepcje innych uczonych, ustala nie do końca jeszcze opisane obszary poznawcze, a następnie podkreśla konieczność rozszerzenia zakresu przestrzeni badawczej: „Jednakże najciekawsze, moim zdaniem, perspektywy otwierają przed badaniem procesu kształtowania stylu indywidualnego, zarówno w perspektywie autobiograficznej (uchwycenie narodzin i rozwoju stylistycznej samoświadomości), jak i w kontekstach interpretacyjnych (konwencji artystycznych, norm kulturowych i obyczajowych, tradycji, wartości kultury, oczekiwań odbiorczych itp.).

Na konieczność rewizji licznych pojęć i terminów dominujących obecnie postaw badawczych zwraca uwagę Maria Wojtak w swoim metodologicznym artykule Felietonista indywidualista, czyli o idiolekcie gatunkowo sprofilowanym (s. 321-332). Analiza lingwistyczna zmierza do odpowiedzi na pytanie: jakie są najważniejsze przejawy twórczej oryginalności funkcjonujące $\mathrm{w}$ ramach profilowania gatunkowego? Punktem wyjścia do odpowiedzi na to pytanie jest $\mathrm{z}$ kolei teza, że profilowanie obejmuje kilka 
kategorii zjawisk, a wśród nich wymienić należy: „a) odmianę gatunkową (jeśli gatunek wykształcił ten rodzaj dyferencji), b) postawę autora wobec prezentowanej rzeczywistości, c) uwzględniane przez twórcę komponenty gatunku (zwłaszcza środki stylistyczne)". Badaczka, odnosząc tak wytyczone cele do gatunku felietonowego - konkretnie do tekstów Jacka Fedorowicza - wyznacza trwałe składniki wzorca, głównie w zakresie tworzywa językowego oraz ujętej w ramy językowe swobody twórczej.

Recenzowana książka niewątpliwie zasługuje na przeczytanie. Jej zaletą jest różnorodność dyscyplinarna i metodologiczna. Naukowcy z różnych ośrodków akademickich, reprezentujący różne dyscypliny humanistyczne, zarówno badacze już bardzo dojrzali, jak też badacze dopiero rozpoczynający swą naukową drogą, analizują, interpretują i odczytują na nowo wcześniejsze ustalenia badawcze, wskazują też wiele inspirujących pomysłów, które w przyszłości mogą stać się przedmiotem bardziej szczegółowych rozważań.

Urszula Sokólska

Uniwersytet w Białymstoku 